\title{
Nerve Growth Factor Increases Nicotinic ACh Receptor Gene Expression and Current Density in Wild-Type and Protein Kinase A-Deficient PC12 Cells
}

\author{
Leslie P. Henderson,, ${ }^{1,2}$ Matthew J. Gdovin, ${ }^{1}$ ChunLei Liu, ${ }^{1}$ Paul D. Gardner,,a and Robert A. Maue ${ }^{1,2}$ \\ Departments of ${ }^{1}$ Physiology and ${ }^{2}$ Biochemistry, Dartmouth Medical School, Hanover, New Hampshire 03755-3833
}

\begin{abstract}
Although neuronal nicotinic ACh receptors (nAChR) play a key role in synaptic transmission and information transfer in the nervous system, little is known about the molecular mechanisms that govern the expression of the multiple subunits that form the receptors and determine their functional properties. Using electrophysiological and molecular biological approaches, we have investigated the NGF-mediated regulation of $\mathrm{nAChR}$ expression in rat pheochromocytoma (PC12) cells and protein kinase A (PKA)-deficient PC12 cells. We report that NGF treatment increases steady state levels of mRNA encoding the $\alpha_{3}, \alpha_{5}, \alpha_{7}, \beta_{2}$, and $\beta_{4}$ subunits, increases the occurrence of $\mathrm{ACh}$-induced single-channel activity in excised patches, and increases $\mathrm{ACh}$-induced macroscopic current density, all by mechanisms independent of PKA activity.

[Key words: ion channel regulation, neuronal nicotinic $\mathrm{ACh}$ receptors, NGF, PC12 cells, protein kinase A, patch-clamp recording, gene expression, mRNAl
\end{abstract}

In the nervous system, information is transmitted across synapses between individual nerve cells by chemical neurotransmitters such as ACh. The binding of these neurotransmitter molecules to specific receptor proteins in postsynaptic neurons is a key step in this process. Changes in the function, expression, or density of the receptor proteins can have profound effects on the efficacy of synaptic transmission, and ultimately influence the integration and modulation of information in the nervous system. Specifically, neuronal nicotinic ACh receptors (nAChR) are $300 \mathrm{kDa}$ complexes composed of five membrane-spanning subunits (Lindstrom et al., 1987; Cooper et al., 1991) that associate to form an ion-conducting pore through the plasma membrane. Molecular cloning studies have identified a family of $\mathrm{AChR}$ subunit genes that exhibit distinct temporal and tissue specific patterns of expression in the PNS and CNS, with at

Received Mar. 9. 1993; revised July 13, 1993; accepted Aug. 5, 1993.

We thank D. Phillips for technical assistance, J. Wagner for the 123.7 cells, J. Boulter for providing $\mathrm{nAChR}$ cDNA clones, $\mathrm{S}$. Froehner for use of his peristaltic pump, J. Dunlap for use of his densitometry equipment, and J. Margiotta and $\mathbf{J}$ Wagner for comments on the manuscript, and P.D.G. thanks B.P. for inspiration. This research was supported by National Institutes of Health Grants NS28668 to L.P.H., NS30243 to P.D.G., and NS28767 to R.A.M., American Heart Association Established Investigatorship 91001490 to L.P.H. and grants from the Amyotrophic Lateral Sclerosis Association to L.P.H. and Alfred P. Sloan Foundation to R.A.M.

Correspondence should be addressed to Dr. Robert A. Maue, Department of Physiology, Dartmouth Medical School, Hanover, NH 03755-3833.

Present address: Institute of Biotechnology, University of Texas Health Science Center at San Antonio, 15355 Lambda Drive, San Antonio, TX 78245-3207.

Copyright (C) 1994 Society for Neuroscience $0270-6474 / 94 / 141153-11 \$ 05.00 / 0$ least six distinct genes encoding $\alpha$ subunits and three genes encoding $\beta$ subunits (Boulter et al., 1986, 1990; Goldman et al., 1987; Deneris et al., 1988a,b; K. Wada et al., 1988; Duvosin et al., 1989; E. Wada et al., 1989; Seguela et al., 1993). Although nAChRs most likely contain two $\alpha$ subunits and three $\beta$ subunits (Cooper et al., 1991), analysis of the electrophysiological and pharmacological properties of various combinations of these subunits suggests a great deal of functional diversity can arise from different combinations of $\alpha$ and $\beta$ subunits (Boulter et al., 1987; Duvosin et al., 1989; Papke et al., 1989; Luetje et al., 1990; Luetje and Patrick, 1991; for review, see Deneris et al., 1991). While the functional implications of this diversity are beginning to be understood, little is known about the molecular mechanisms governing the expression of nAChRs, despite evidence that neurotrophic factors, such as NGF, play an important role. For example, NGF increases ACh current density in primary sensory neurons (Cooper and Lau, 1986; Mandelzys et al., 1990; Mandelzys and Cooper, 1992). In addition, NGF induces an increase in $\mathrm{ACh}$ sensitivity in the rat pheochromocytoma (PC12) cell line (Dichter et al., 1977; Ifune and Steinbach, 1990a).

Neurotrophins, such as NGF, are expressed early in development (for revicw, sce Levi-Montalcini, 1987; Bothwell, 1991) and play a critical role in the development and maintenance of both the PNS and CNS (for review, see Levi-Montalcini, 1987; Gage et al., 1991; Wagner and Kostyk, 1991). In particular, NGF influences the survival, growth, and differentiation of sympathetic and sensory neurons of the PNS and selective populations of cholinergic neurons in the CNS (for review, see LeviMontalcini, 1987; Barde, 1989). In addition, NGF induces PC12 cells to differentiate and acquire characteristics of sympathetic neurons (Greene and Tischler, 1976). The dramatic transformation that occurs in PC12 cells in response to NGF includes cessation of cell division, formation of long neurites, an increase in the synthesis of neurotransmitters, an increase in the expression of voltage-dependent sodium ( $\mathrm{Na}$ ) channels, and an increase in sensitivity to ACh (for review, see Greene and Tischler, 1982; Halegoua et al., 1991).

The interaction of NGF with specific cell surface receptors induces neuronal differentiation through the coordinate recruitment of a variety of cellular control mechanisms. The product of the proto-oncogene $t r k$, pl40 $0^{r k}$, either alone or in association with a $75 \mathrm{kDa}$ membrane-spanning protein, p75 (Johnson et al., 1986; Radeke et al., 1987), serves as the high-aftinity receptor for NGF (Hempstead et al., 1991; Kaplan et al., 199 la,b; Klein et al., 1991; for discussion, see Barker and Murphy, 1992; Chao, 1992; Meakin and Shooter, 1992). When NGF binds to its high- 
affinity receptor, the intrinsic tyrosine kinase activity of $\mathrm{p} 140^{\mathrm{rrk}}$ is rapidly induced (Kaplan et al., 1991 b; Klein et al., 1991) and initiates a signaling cascade that involves a wide variety of second messenger pathways, including those associated with changes in phospholipid turnover, intracellular calcium, arachidonic acid, cAMP, and ras activity. A variety of protein kinases, including S6 kinase, protein kinase $\mathrm{C}$ (PKC), cAMP-dependent protein kinase A (PKA), and the extracellular signal-regulated kinases, have also been implicated in mediating the effects of NGF (for review, see Haleguoa et al., 1991). These rapidly occurring changes trigger an enormous cascade of gene expression, with the activation of immediate-early genes, encoding proteins such as $c-f o s, c-j u n$, and $j u n-B$, occurring within minutes after exposure to NGF (Bartel, et al., 1989; for review, see Morgan and Curren, 1989). These proteins then appear to serve as transcription factors that subsequently activate genes associated with the neuronal phenotype (Gizang-Ginsberg and Zifr, 1990; for review, see Haleguoa et al., 1991).

In particular, the role of PKA in mediating the effects of NGF has received considerable scrutiny (for review, see Greene and Tischler, 1982; Haleguoa et al., 1991). The treatment of PC12 cells with permeable analogs of cAMP appears to mimic some of the responses to NGF and cause some of the same changes in protein phosphorylation (Haleguoa and Patrick, 1980; Erny et al., 1981; Cremins et al., 1986). Analyses of PKA-deficient cells have revealed NGF-mediated responses that are dependent upon PKA activity (Cremins et al., 1986; Ginty et al., 1992), but have also clearly shown that there are responses to NGF that can occur via PKA-independent mechanisms (Damon et al., 1990; Ginty et al., 1991). While the role of PKA in the NGFmediated induction of $\mathrm{Na}$ channels in PC12 cells has been investigated (Kalman et al., 1990; Pollock et al., 1990; Ginty et al., 1992), its involvement in the NGF-mediated induction of nAChRs has not been determined.

In the present study, we have exploited the experimental advantages associated with PC12 cells and the fact that they express $n A C h R$ to analyze the mechanisms underlying the NGFmediated regulation of $\mathrm{ACC} R \mathrm{R}$ expression. Using single-channel and whole-cell patch-clamp recording, as well as Northern blot hybridization analysis, we find that NGF treatment increases the steady state levels of mRNA encoding the $\alpha_{3}, \alpha_{5}, \alpha_{7}, \beta_{2}$, and $\beta_{4}$ subunits, increases the occurrence of $\mathrm{ACh}$-induced singlechannel activity in excised membrane patches, and increases ACh-activated macroscopic current density, all by mechanisms independent of PKA activity.

\section{Materials and Methods}

Cell culture and reagents. Cells were maintained in a humidified $\mathrm{CO}_{2}$ environment in Dulbecco's Modified Eagle's Medium (DMEM) containing $0.45 \%$ glucose, $10 \%$ fetal bovine serum, $5 \%$ heat inactivated horse serum, $100 \mathrm{U} / \mathrm{ml}$ penicillin, and $100 \mu \mathrm{g} / \mathrm{ml}$ streptomycin (GIBCO, Grand Island, NY). The 123.7 cells, generously provided by J. Wagner (Cornell Medical Center), were maintained in media that contained 500 $\mu \mathrm{g} / \mathrm{ml} \mathrm{G} 418$ (GIBCO). Media were changed every other day, and cells were passaged once a week. Cells were grown in $100 \mathrm{~mm}$ (for RNA) or $35 \mathrm{~mm}$ (for electrophysiology) tissue culture dishes (Falcon). When appropriate, cells were treated with $100 \mathrm{ng} / \mathrm{ml}$ of $7 \mathrm{~S} \mathrm{NGF}$ (Upstate Biotechnology, Inc., Plattsburg, NY) for $7 \mathrm{~d}$, with fresh growth factor added each time the media were changed.

Electrophysiological recording and analysis. Prior to recording, a plastic insert was placed inside of a $35 \mathrm{~mm}$ culture dish containing cells and held into place with Vaseline petroleum jelly, forming a $0.5 \mathrm{ml}$ chamber that was continuously perfused at $1 \mathrm{ml} / \mathrm{min}$ with an extracellular saline solution $(150 \mathrm{~mm} \mathrm{NaCl}, 5 \mathrm{~mm} \mathrm{KCl}, 1 \mathrm{~mm} \mathrm{CaCl}, 1 \mathrm{~mm}$
$\mathrm{MgCl}_{2}, 5$ mm HEPES, 5 mm glucose). In initial experiments, 500 пм atropine was included in the extracellular solution; however, inclusion of atropine did not cause discernible changes in the results obtained, and it was omitted from further experiments because of a reported blocking effect on the inward currents elicited by ACh (Ifune and Steinbach, 1990b). Cells were viewed at a magnification of $640 \times$ using a Zeiss Axiovert inverted microscope equipped with Hoffman modulation contrast optics. Patch-clamp recordings (Hamill et al., 1981) were made at room temperature $\left(20-24^{\circ} \mathrm{C}\right)$ using a List EPC.-7 patch-clamp amplifier (Medical Systems Corp., Greenvale, NY). Patch electrodes were pulled from capillary glass (Sutter Instruments, Novato, CA) and had resistances of 3-7 M $\Omega$ when filled with an internal saline solution (140 $\mathrm{mm} \mathrm{CsCl}, 10 \mathrm{~mm}$ EGTA, $10 \mathrm{~mm}$ HEPES, pH 7.2). For the whole-cell recordings, electrode tips were coated with Sylgard (Dow Corning, Midland, MI) to minimize electrode capacitance. Puffer electrodes contained ACh (acetylcholine chloride; Sigma Chemical Co., St. Louis, MO) dissolved in the extracellular saline solution. Puffer electrodes used for the whole-cell experiments contained $100 \mu \mathrm{M}$ ACh, had tip diameters of $5-$ $10 \mu \mathrm{m}$, and were placed $\sim 30 \mu \mathrm{m}$ from the cell. For the single-channel experiments, puffer electrodes contained $10 \mu \mathrm{M} \mathrm{ACh}$, had tip diameters of $1-5 \mu \mathrm{m}$, and were placed $\sim 30 \mu \mathrm{m}$ from the membrane patch. Voltage commands were applied, current measurements were stored, and pressure application ( $3 \mathrm{psi}$ ) of $\mathrm{ACh}$ from the puffer electrodes was controlled using an Atari computer-based acquisition system and software (Instrutech Corp., Elmont, NY). For the whole-cell recordings, the cell membrane potential was clamped to $-80 \mathrm{mV}$, and a computer-driven system simultaneuously applied a $5 \mathrm{sec}$ pressure pulse to the back of a puffer electrode containing $\mathrm{ACh}$ while recording the current responses from the patch-clamp electrode. Electronic compensation was used to reduce the effective series resistance and the time constant of membrane charging, and provided measurements of access resistance and cell membrane capacitance. Series resistance compensation of $60-75 \%$ was routinely used. Data were analyzed from cells with estimated series resistance errors of $5 \mathrm{mV}$ or less. When possible, subsequent to the application of $\mathrm{ACh}$, voltage-dependent $\mathrm{Na}$ currents were assayed using previously established procedures (Ginty et al., 1992), and the current versus voltage relationship and the kinetic parameters of the Na currents were used as additional indications of the quality of the voltage clamp. For the whole-cell recordings, the current signal was low-pass filtered at $4 \mathrm{kHz}$, and then digitally filtered at $2 \mathrm{kHz}$ for storage and off-line analysis. The macroscopic current decay was fitted with two exponential components using an iterative fitting routine developed by F. J. Sigworth for Instrutech Corp. The peak current and the estimate of cell membrane capacitance (as an indication of membrane area) were used to calculate $\mathrm{ACh}$ current density. For single-channel recordings, the membrane potential was held at -80 to $-140 \mathrm{mV}$, and $10 \mu \mathrm{M}$ ACh was applied every $1-5$ min for $10 \mathrm{sec}$. The current signal was low-pass filtered at $10 \mathrm{kHz}$, and then digitally filtered at $4 \mathrm{kHz}$ for storage and off-line analysis. Analysis was done as previously described (Brennan et al., 1992) using commercially available software (Instrutech Corp.). Slope conductances were estimated by linear regression, using the mean single-channel amplitudes at membrane potentials between $-80 \mathrm{mV}$ and $-140 \mathrm{mV}$. Minimum gap duration for burst duration analysis was set at $5 \mathrm{msec}$. The fraction of time open, as an indication of open probability, was estimated using commercially available software (F. J. Sigworth, Instrutech Corp.) and calculated as the sum (for current levels 1 through $n$ ) of the dwell time at each current level multiplied by the level number and divided by the total recording time. Values given in the text are mean $+\mathrm{SEM}$. Statistical significance was determined using a two-tailed Student's $t$ test.

RNA isolation and Northern blot analysis. Cells plated at $\sim 10^{6}$ cells per $100 \mathrm{~mm}$ tissue culture dish were harvested, total cellular RNA isolated from them by the method of Chirgwin et al. (1979), and $40 \mu \mathrm{g}$ samples size-fractionated on $1.0 \%$ agarose gels containing $2.0 \mathrm{M}$ formaldehyde. Following electrophoresis, the RNA was transferred to a nylon membrane (Zetabind, Cuno, Inc., Meridan, CT) overnight and the membrane baked at $80^{\circ} \mathrm{C}$ for $2 \mathrm{hr}$. Northern blot hybridization was then performed similar to that described in Boulter et al. (1990). Blots were prehybridized for $3 \mathrm{hr}$ at $42^{\circ} \mathrm{C}$ in $1 \mathrm{M} \mathrm{NaCl}, 50 \%$ formamide, $10 \%$ dextran sulfate, $50 \mathrm{~mm}$ Tris $\mathrm{pH} 7.5,1 \% \mathrm{SDS}, 100 \mu \mathrm{g} / \mathrm{ml}$ denatured salmon sperm DNA. The blots were then hybridized with randomprimed cDNA probes generated using a commercially available kit (Bethesda Research Laboratories, Grand Island, NY) and ${ }^{32}$ P-labeled dCTP. nAChR cDNAs were generously provided by Dr. J. Boulter (The Salk Institute). Probes generated from these clones have been used in pre- 
Table 1. Kinetic properties of the ACh-induced macroscopic currents in PC12 and PKA-deficient 123.7 cells

\begin{tabular}{|c|c|c|c|c|}
\hline & $T_{\text {pcak }}(\mathrm{m} / \mathrm{sec})$ & $\tau_{\text {fast }}(\mathrm{sec})$ & $\tau_{\text {slow }}(\mathrm{sec})$ & $\%_{\text {fast }}$ \\
\hline $\mathrm{PCl} 2$ & $\begin{array}{l}107.0 \pm 10.1 \\
(n=34)\end{array}$ & $\begin{array}{l}0.31 \pm 0.04 \\
(n=34)\end{array}$ & $\begin{array}{l}5.53 \pm 1.09 \\
(n=18)\end{array}$ & $\begin{array}{l}82.8 \pm 3.3 \\
(n=34)\end{array}$ \\
\hline $\mathrm{PC} 12+\mathrm{NGF}$ & $\begin{array}{l}137.8 \pm 11.1 \\
(n=33)\end{array}$ & $\begin{array}{l}0.41 \pm 0.05 \\
(n=33)\end{array}$ & $\begin{array}{l}4.11 \pm 0.65 \\
(n=27)\end{array}$ & $\begin{array}{l}81.2 \pm 2.7 \\
(n=33)\end{array}$ \\
\hline 123.7 & $\begin{array}{l}93.1 \pm 13.7 \\
(n=23)\end{array}$ & $\begin{array}{l}0.33 \pm 0.04 \\
(n=22)\end{array}$ & $\begin{array}{l}4.86 \pm 0.75 \\
(n=18)\end{array}$ & $\begin{array}{l}72.0 \pm 4.2 \\
(n=20)\end{array}$ \\
\hline $123.7+\mathrm{NGF}$ & $\begin{array}{l}113.6 \pm 10.6 \\
(n=22)\end{array}$ & $\begin{array}{l}0.38 \pm 0.05 \\
(n=21)\end{array}$ & $\begin{array}{l}5.24 \pm 1.27 \\
(n=20)\end{array}$ & $\begin{array}{l}71.0 \pm 5.0 \\
(n=21)\end{array}$ \\
\hline
\end{tabular}

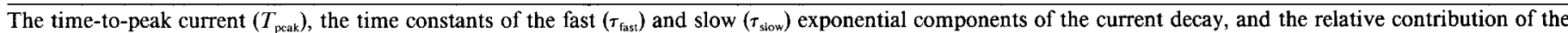

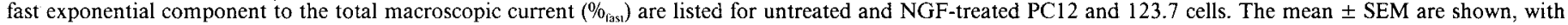
the number of cells in each group indicated in parentheses.

vious studies to detect nAChR transcripts (Boulter et al., 1990; Rogers et al., 1992), and for $\alpha_{2}$ consisted of a 1931 base pair (bp) EcoRI fragment corresponding to nucleotides - 385 to 1546; for $\alpha_{3}$, a $1858 \mathrm{bp} \mathrm{EcoRI/}$ HindIII fragment corresponding to nucleotides -151 to 1707 ; for $\alpha_{4}$, a 2110 bp HindIII fragment corresponding to nucleotides -21 to 2089 ; for $\alpha_{5}$, a $1607 \mathrm{bp}$ PstI fragment corresponding to nucleotides -183 to 1424; for $\alpha_{6}$, a $1760 \mathrm{bp}$ HindIII/Pst fragment corresponding to inucleotides -277 to 1483 ; for $\alpha_{7}$, a $2105 \mathrm{bp} \mathrm{KpnI/SmaI} \mathrm{fragment} \mathrm{corre-}$ sponding to nucleotides -99 to 2017 ; for $\beta_{2}$, a 2196 bp EcoRI fragment corresponding to nucleotides - 179 to $201 \%$; for $\beta_{3}$, a $2130 \mathrm{bp}$ EcokI fragment corresponding to nucleotides -258 to 1872 ; and for $\beta_{4}$, a 2522 bp EcoRI/XhoI fragment corresponding to nucleotides -135 to 2387. Probes were added to the prehybridization solution at a final activity of $10^{6} \mathrm{cpm} / \mathrm{ml}$. After a $14 \mathrm{hr}$ hybridization at $65^{\circ} \mathrm{C}$, the membrane was washed two times ( $30 \mathrm{~min}$ each) at room temperature in $2 \times$ SSPE $(0.75$ м NaCl, 57 mм Na $\mathrm{HPO}_{4}, 5$ mм EDTA, pH 7.4), 0.5\% SDS, two times (30 min each) at $65^{\circ} \mathrm{C}$ in $0.2 \times$ SSPE, $0.5 \%$ SDS, and then exposed to Kodak XAR film at $-80^{\circ} \mathrm{C}$ for $7-72 \mathrm{hr}$. The blots were subsequently reprobed with an RNA probe specific for the $\sim 1$ kilobase $(\mathrm{kb})$ cyclophilin mRNA. The cyclophilin probe, generated using a cyclophilin cDNA (generously provided by C. Machida, Oregon Health Sciences University), a commercially available kit (Promega Corp., Madison, WI) and ${ }^{32}$ P-labeled CTP, was added to the blots at a final activity of $5 \times 10^{\circ} \mathrm{cpm} / \mathrm{ml}$. After a $14 \mathrm{hr}$ hybridization, the blot was washed and exposed to Kodak XAR film at $-80^{\circ} \mathrm{C}$ for $15-30 \mathrm{~min}$. After densitometric analysis of the autoradiographic densities representing the nAChR and cyclophilin mRNAs using the NIH IMAGE program, nAChR signals in the samples were normalized to their respective cyclophilin signal before being compared to each other.

\section{Results}

$N G F$ increases $A C h$-induced macroscopic current density in PC12 and PKA-deficient PC12 cells

Whole-cell currents elicited by pressure application of $\mathrm{ACh}$ from a puffer electrode were recorded from cells maintained in tissue culture dishes in the presence or absence of NGF for $7 \mathrm{~d}$. The cell membrane potential was clamped to $-80 \mathrm{mV}$, and a computer-driven system simultaneously applied a $5 \mathrm{sec}$ pressure pulse to the back of a puffer electrode containing $100 \mu \mathrm{M} \mathrm{ACh}$ while recording the current responses from the patch-clamp electrode. Peak currents were normalized to cell capacitance (see Materials and Methods) in order distinguish changes in current density from changes in current magnitude arising simply from increases in cell size. After the ACh-induced currents were recorded, voltage-dependent Na currents were recorded using previously established procedures (Ginty et al., 1992). The current versus voltage relationship and kinetic parameters of the $\mathrm{Na}$ currents were used as additional indications of the quality of the voltage clamp. In addition, for PC12 cells, the induction of functional $\mathrm{Na}$ channel expression helped to verify that the cells had responded to NGF treatment. While almost all untreated
PC.12 cells ( 31 of 35 ) exhibited a discernible response to ACh $(>20 \mathrm{pA}$ ), the responses were generally small (Fig. $1 A$ ), and in most of the cells ( 21 of 35 ) the peak amplitude of the inward current was less than $100 \mathrm{pA}$. The peak current occurred within $\sim 100 \mathrm{msec}$ of the onset of the pressure applications of $\mathrm{ACh}$, and the subsequent decline, presumably due to receptor desensitization, could be adequately described by the sum of two exponential components, one with a time constant $\left(\tau_{\text {fast }}\right)$ of 0.3 $0.4 \mathrm{sec}$, the other with a time constant $\left(\tau_{\text {stow }}\right)$ of $4-5 \mathrm{sec}$ (Table 1). The fast component was predominant in all cases, accounting for $\sim 80 \%$ of the total current (Table 1 ). The values for the timeto-peak current, the time constants of the two components, and the predominance of the fast component are consistent with previous results from PC1 2 cells (Ifune and Steinbach, 1990a) and primary ncurons (Margiotta ct al., 1987) using similar experimental approaches. Upon treatment with NGF, there was a dramatic increase in the magnitude of the ACh-induced currents (Fig. $1 A$ ). There was also a substantial increase in cell membrane capacitance (Fig. 2 caption), presumably reflecting the NGF-induced hypertrophy of PC 12 cells (Greene and Tischler, 1976). Despite the increase in cell size, current densities observed for individual cells treated with NGF were often greater than $50 \mathrm{pA} / \mathrm{pF}$ (11 of 33), values never observed for untreated PC1 2 cells ( 0 of 35 ). Overall, NGF treatment caused a significant increase $(2.7$-fold; $p<0.05)$ in the average $\mathrm{ACh}$-induced macroscopic current density (Fig. 2). In contrast, NGF-induced changes in ACh sensitivity were not accompanied by apparent changes in the kinetics of the whole-cell currents (Table 1).

The effect of NGF on the density of ACh-induced currents was also determined in two sublines of PC1 2 cells (123.7 and $\Lambda \mathrm{B}-11$ ) rendered $\mathrm{PK} \Lambda$-deficient through the stable incorporation and overexpression of mutant regulatory subunits of PKA (Ginty et al., 1991). As judged from biochemical assays of PKA activity, $90 \%$ of the cAMP-dependent activation of PKA is inhibited in these cells, and in response to NGF the inhibition occurs to an even greater extent due to a marked increase in the expression of the mutant regulatory subunit but not the endogenous regulatory subunit (Ginty et al., 1991). Functionally, the phosphorylation of tyrosine hydroxylase, ribosomal S6, and histone $2 \mathrm{~B}$, the increase in ornithine decarboxylase (ODC) activity, and the induction of neurite outgrowth that normally occur in wild-type PC12 cells in response to cAMP analogs are undetectable in the PKA-deficient cells treated with dibutyryl-cAMP, although these changes occur in the PKA-deficient cells in response to NGF (Ginty et al., 1991). In addition, in the present study the cAMP analog 8-(4-chlorophenyl-thio)adenosine $3^{\prime}, 5^{\prime}$ - 
A

$\mathrm{ACh}$

PC12

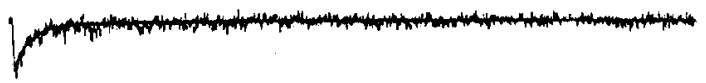

$\mathrm{PC} 12+\mathrm{NGF}$

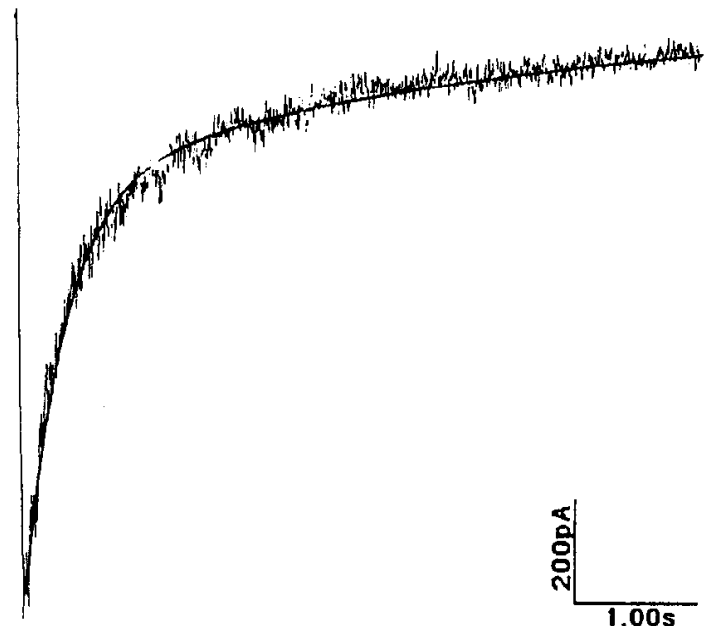

$\mathrm{ACh}$

123.7

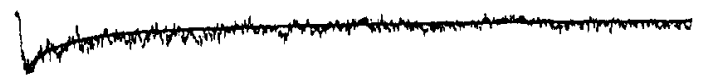

$123.7+N G F$

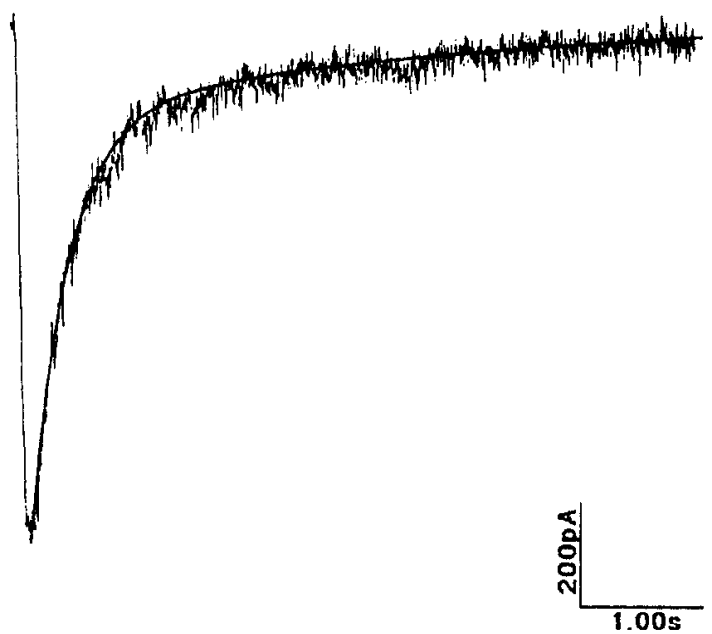

Figure 1. NGF treatment increases the whole-cell macroscopic currents induced by ACh in PC12 and PKA-deficient PC12 cells. Shown are representative records of ACh-induced currents in untreated and NGF-treated PC12 cells $(A)$ and untreated and NGF-treated 123.7 cells $(B)$. The duration of the pressure application of $\mathrm{ACh}$ from the puffer electrode is indicated by the solid bar above the current records. A solid line fitted to the decline of the current from its peak value is superimposed on the current records, and represents the sum of the fast and slow decaying exponential components of the current. Estimated time constants of the fast and slow decaying components for these four representative cells were $\tau_{\text {fast }}=0.21 \mathrm{msec}, \tau_{\text {slow }}=1.96 \mathrm{msec}$ (untreated PC1 2 cell); $\tau_{\text {fast }}=0.33 \mathrm{msec}, \tau_{\text {slow }}=3.90 \mathrm{msec}$ (NGF-treated PC12 cell); $\tau_{\text {fast }}=0.27 \mathrm{msec}, \tau_{\text {slow }}=3.20$ msec (untreated 123.7 cell); and $\tau_{\text {fast }}=0.32 \mathrm{msec}, \tau_{\text {slow }}=3.59 \mathrm{msec}$ (NGF-treated $123.7 \mathrm{cell}$ ). The average time constants are shown in Table 1 .

cyclic monophosphate (8-CPT-cAMP) failed to elicit neurite outgrowth or an increase in ODC activity in these PKA-deficient cells (L. P. Henderson and R. A. Maue, unpublished observations). With regard to functional $\mathrm{nAChR}$ expression, untreated 123.7 cells were similar to untreated PC12 cells in that most of them (23 of 26) had small, yet discernible responses to $\mathrm{ACh}$ (Fig. $1 B$ ). The peak current occurred within $\sim 100 \mathrm{msec}$ and the subsequent decline in current could be adequately described by two exponential components with time constants of $\sim 0.3 \mathrm{sec}$ and $\sim 5 \mathrm{sec}$, with the fast component predominant in all cases (Table 1). More importantly, despite the PKA deficiency, NGF treatment still elicited a dramatic increase in the magnitude of the $\mathrm{ACh}$-induced currents in these cells (Fig. $1 B$ ). In contrast, NGF treatment failed to elicit an increase in voltage-dependent
$\mathrm{Na}$ channel expression in 123.7 cells (data not shown), in agreement with our previous results indicating that NGF-induced $\mathrm{Na}$ channel expression was PKA-dependent (Ginty et al., 1992). Despite the accompanying increase in cell membrane capacitance (Fig. 2 caption), the density of $\mathrm{ACh}$-induced current in the NGF-treated 123.7 cells was often larger than observed for untreated 123.7 cells. As with PC12 cells, current densities exhibited by NGF-treated 123.7 cells often exceeded $50 \mathrm{pA} / \mathrm{pF}$ (7 of 21), values never observed in untreated cells ( 0 of 26). Overall, NGF treatment induced a 2.8 -fold increase in the average density of the ACh-induced current, similar to that observed in PC1 2 cells (Fig. 2). Furthermore, although there was a significant increase in the density of the ACh-induced currents in 123.7 cells in response to NGF ( $p<0.05$ ), there were no apparent 
changes in the kinetics of the whole-cell currents (Table 1). Analysis of the PKA-deficient AB-11 cells produced similar results (data not shown) and, when combined with the results obtained from the 123.7 cells, provides strong evidence that the NGF-mediated increase in the density of ACh-induced currents does not require PKA activity.

\section{$N G F$ increases $A C h$-induced single-channel activity in} membrane patches from $\mathrm{PC} 12$ and PKA-deficient PC12 cells

Neuronal $n A C h R s$ with different functional properties, including differences in mean channel open time and single-channel conductance, have been described (Bormann and Matthaei, 1983; Margiotta and Gurantz, 1989; Papke et al., 1989; Papke and Heinemann, 1991; Ifune and Steinbach, 1990b, 1991; Listerud et al., 1991). While analysis of whole-cell currents is useful for revealing the NGF-mediated increase in the density of $\mathrm{ACh}$ induced currents, single-channel analysis provides a direct means of characterizing the functional properties of the individual nAChRs, and determining whether NGF treatment, the lack of PKA activity, or both, influences these properties. Therefore, single-channel recordings were made from outside-out patches of membrane during $10 \mathrm{sec}$ applications of $10 \mu \mathrm{M} \mathrm{ACh}$ from a puffer electrode. In patches containing functional channels, there was a clear onset of single-channel activity in response to $\mathrm{ACh}$ (Fig. 3A). This activity was not observed when the puffer electrode contained only saline, was not abolished when atropine was included in the puffer solution, and did not differ substantially from the ACh-dependent activity observed in cell-attached recordings (data not shown). Although in most cases single-channel activity ceased during the course of the $10 \mathrm{sec}$ ACh application, activity occasionally continued for brief periods of time beyond this. Only the single-channel activity occurring during the application of ACh was included for analysis.

Single-channel activity was elicited by ACh in 23\% (20 of 87 ) of the membrane patches excised from untreated PC12 cells (Fig. $3 B$ ). Nearly all ACh-induced events could be attributed to one class, which had a slope conductance of $43.4 \pm 2.5 \mathrm{pS}(n$ $=6)$ and an average burst duration at $-80 \mathrm{mV}$ of $12.92 \pm 3.41$ msec $(n=10)$. In the NGF-treated cells, the percentage of patches with $\mathrm{ACh}$-induced activity was 2.7 -fold higher $(62 \%, 51$ of 82 ), corresponding closely to the increase in macroscopic current density observed in the whole-cell recordings. In addition, the percentage of patches with simultaneous openings of more than one nAChR channel increased from $22 \%$ for untreated cells to $37 \%$ for treated cells. The increase in single-channel activity was not accompanied by obvious changes in single channel conductance (Fig. $3 C$ ) or mean burst duration, and in NGF-treated PC1 2 cells, nearly all ACh-induced events could be attributed to channels with a slope conductance of $47.6 \pm 5.5 \mathrm{pS}(n-6)$ and a mean burst duration at $-80 \mathrm{mV}$ of $11.02 \pm 2.14 \mathrm{msec}$ $(n=21)$. For patches that had only a single channel active at a time, the fraction of time open was calculated (see Materials and Methods) and was not significantly different in patches from treated and untreated PC1 2 cells (data not shown)

The single-channel activity induced by $\mathrm{ACh}$ in both the untreated and NGF-treated 123.7 cells was noticeably similar to that observed in $\mathrm{PC} 12$ cells (Fig. $3 \mathrm{~B}$ ). ACh-induced single channel activity was detected in $25 \%$ (14 of 57 ) of the patches from untreated 123.7 cells, and increased 2.3-fold to $56 \%$ (27 of 48) when patches from NGF-treated 123.7 cells were analyzed. As with PC1 2 cells, the percentage of patches with simultaneous openings of more than one $\mathrm{ACC}$ R channel increased with NGF treatment, from $0 \%$ for untreated cells to $30 \%$ for treated cells.

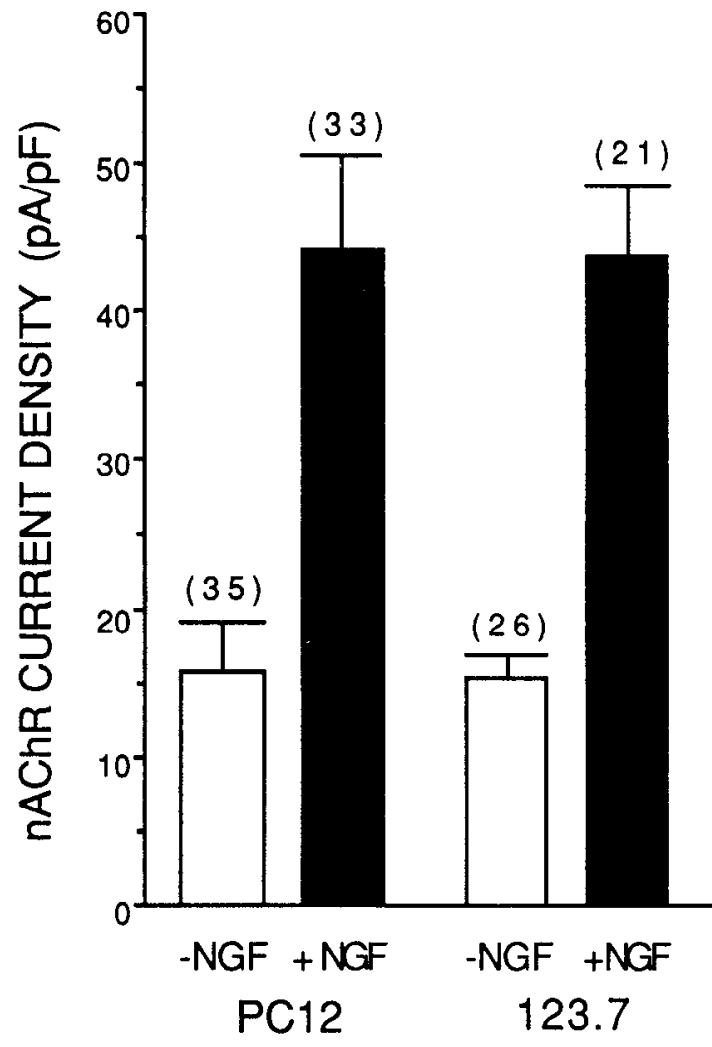

Figure 2. NGF treatment increases the average $\mathrm{ACh}$-induced current density in PC12 and PKA-deficient 123.7 cells. The number of cells in each group is indicated in parentheses. The SEM is shown as an error bar. The average cell membrane capacitance (mean \pm SEM) for PC12 cells was $6.5 \pm 0.2 \mathrm{pF}(n=35)$, for NGF-treated PC12 cells was 15.0 $\pm 0.9 \mathrm{pF}(n=33)$, for 123.7 cells was $9.6 \pm 0.5 \mathrm{pF}(n=26)$, and for NGF-treated 123.7 cells was $15.5 \pm 1.0 \mathrm{pF}(n=21)$.

Nearly all ACh-induced events recorded in 123.7 cells could be attributed to a single conductance class of $44.2 \pm 3.7 \mathrm{pS}(n=$ $6)$, with a mean burst duration at $-80 \mathrm{mV}$ of $13.79 \pm 4.05$ msec $(n=6)$. Comparable activity was also observed in the AB11 subline of PKA-deficient PC12 cells (data not shown). When $\mathrm{ACh}$-induced events were recorded from membrane patches of NGF-treated 123.7 cells, similar values were obtained for the slope conductance $(50.0 \pm 3.9 \mathrm{pS} ; n=6)$ and mean burst duration at $-80 \mathrm{mV}(17.84 \pm 4.29 \mathrm{msec} ; n=18)$. When patches with only a single $n A C h R$ channel active at a time were analyzed, the fraction of time open was not significantly different between treated and untreated 123.7 cells, and was similar to that observed in patches from PC12 cells.

In both the untreated and NGF-treated PC 12 and 123.7 cells, events of both smaller and larger amplitude than the major class of events described above were occasionally observed (Fig. $3 B$ ). Heterogeneity in the functional classes of $\mathrm{nAChR}$ expressed in PC12 cells, with a predominant conductance class and other rarely observed channel types, has been reported in previous studies (Bormann and Matthaei, 1983; Ifune and Steinbach, $1990 \mathrm{~b}, 1991)$. However, both the low frequency of occurrence of these smaller and larger events and the "rundown" or "dropout" observed for $\mathrm{nAChR}$ activity in excised patches (Ifune and Steinbach, 1991; Vernino et al., 1992) precluded further characterization beyond the observation that their frequency in relation to the major conductance class did not appear to be affected by NGF treatment or PKA deficiency (L. P. Henderson 
A

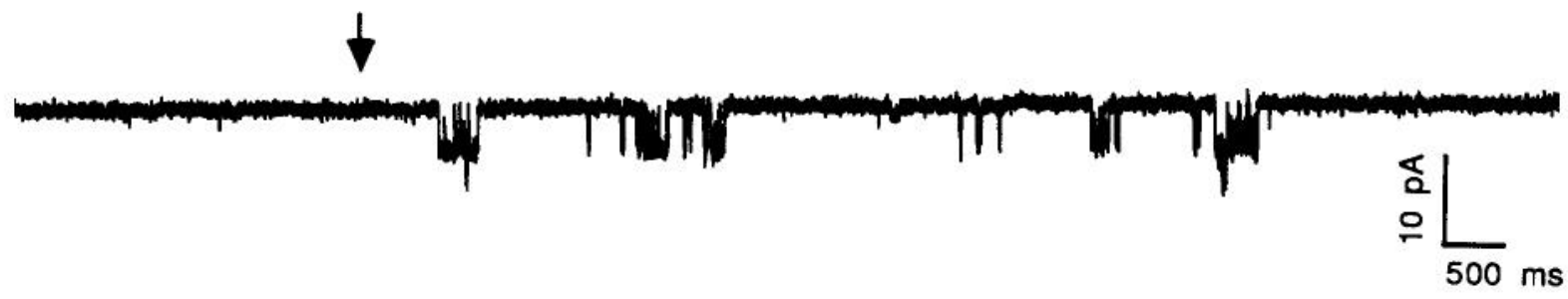

PC12

123.7
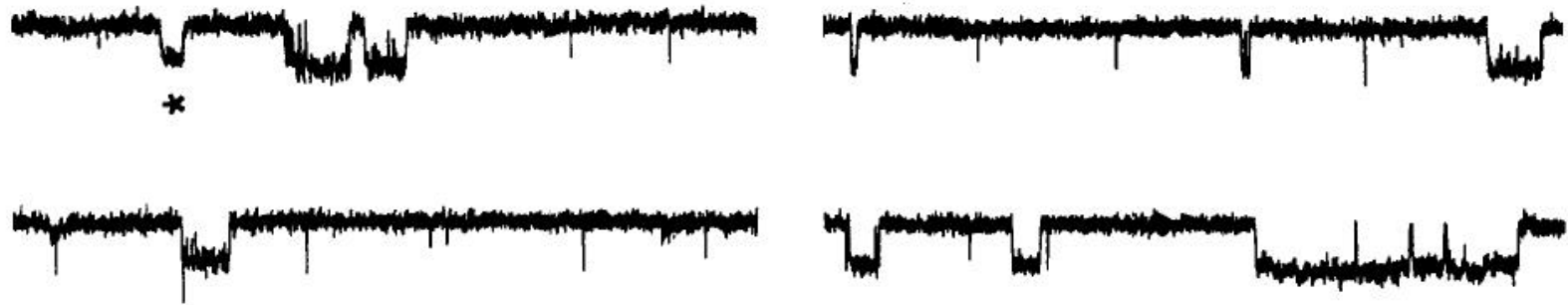

$\mathrm{PC} 12+\mathrm{NGF}$

123.7 + NGF

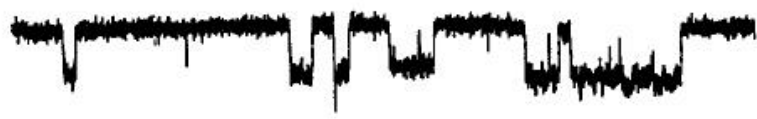

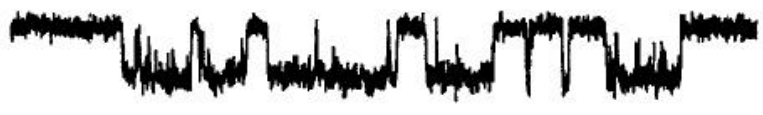
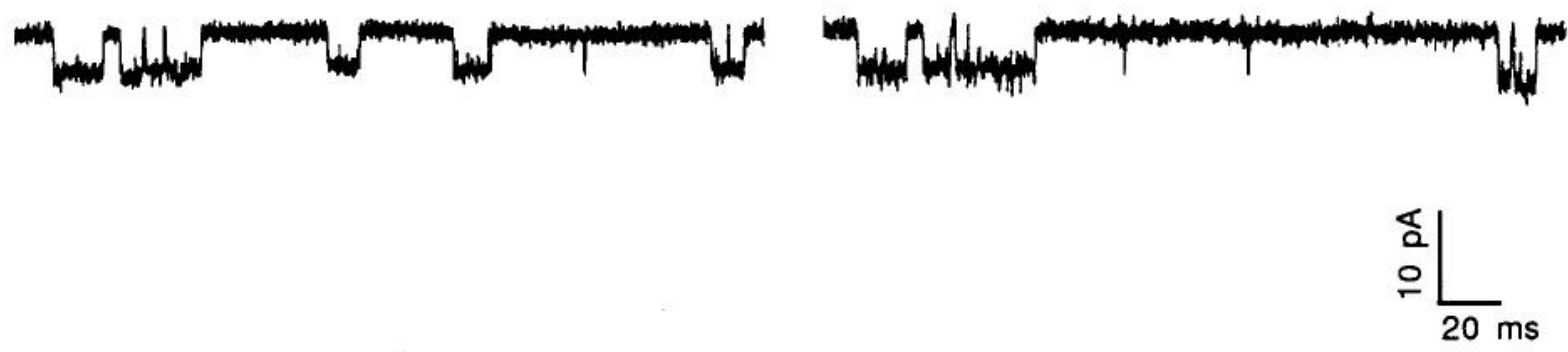

C
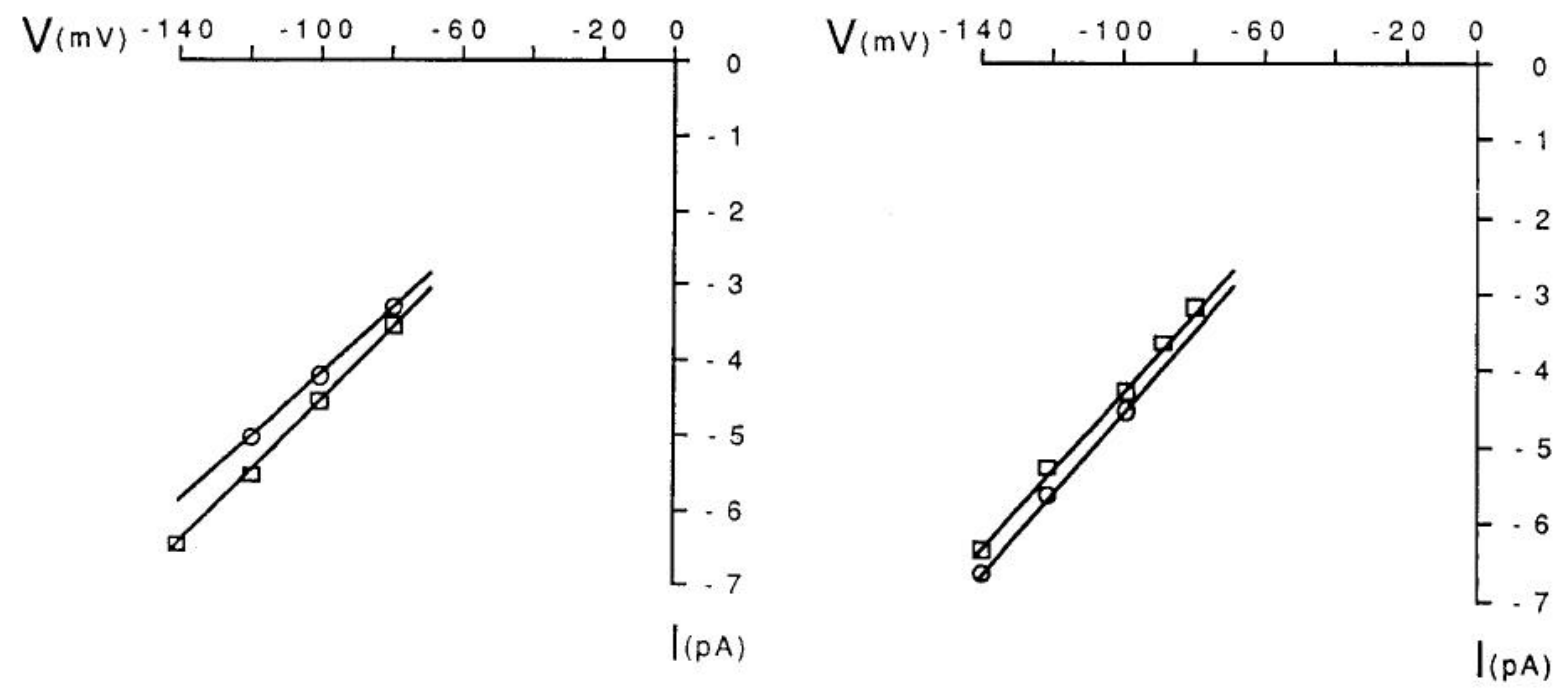
and R. A. Mave, unpublished observations). Instead, the overall results suggest that the $\mathrm{ACh}$-induced response of both untreated and NGF-treated PC12 cells is primarily due to the activity of a 43-50 pS channel and that the functional characteristics of nAChRs in untreated and NGF-treated PC12 cells are not dramatically altered by the absence of PKA activity.

\section{NGF increases nAChR gene expression in PC12 and PKA-deficient PC12 cells}

To begin to investigate the molecular events underlying the increase in ACh sensitivity that occurs in PC1 2 cells in response to NGF, the expression of RNA transcripts encoding $\mathrm{nAChR}$ subunits was measured using Northern blot analysis. The RNA from untreated and NGF-treated cells was probed with ${ }^{32} \mathrm{P}$ labeled cDNA probes under hybridization conditions that allowed subunit-specific mRNA transcripts to be detected (Boulter et al., 1990; Rogers et al., 1992). To quantitate changes in nAChR mRNA levels and control for variations in RNA loading, densitometry was used to analyze the nAChR signals and normalize them to the signal for cyclophilin mRNA, which is constitutively expressed in PC 12 cells and unaffected by growth factor treatment (Machida et al., 1989).

As shown in Figure 4, untreated PCl 2 cells expressed RNA transcripts corresponding to the $\alpha_{3}, \alpha_{5}, \alpha_{7}, \beta_{2}$, and $\beta_{4}$ nAChR subunits. In contrast, RNA corresponding to the $\alpha_{2}, \alpha_{4}, \alpha_{6}$, and $\beta_{3}$ subunits were not detected, even when blots were exposed to film for 72-96 hr (data not shown). Multiple transcripts were evident for the $\alpha_{3}, \alpha_{5}$, and $\beta_{4}$ subunits, consistent with previous reports (Boulter et al., 1986, 1990; Rogers et al., 1992). Multiple transcripts for the $\beta_{2}$ subunit, similar to those reported in earlier studies (Boulter et al., 1990), were also evident upon exposure of the blots to film for longer periods of time (data not shown). In NGF-trcated PC1 2 cclls, the samc nAChR transcripts were expressed as in the untreated cells (Fig. 4). However, in all cases there were 1.5-2.5-fold increases in the steady state levels of mRNA encoding the individual subunits, with the multiple transcript forms for a given subunit appearing to be equally affected (Fig. 4). The increases in $\alpha_{3}, \alpha_{5}, \alpha_{7}, \beta_{2}$, and $\beta_{4}$ subunit mRNAs were consistently observed in separate experiments with different platings of cells and different lots of growth factor. Furthermore, when expression of $\alpha_{3}$ and $\beta_{4}$ transcripts was analyzed in PC 12 cells obtained from three additional sources, NGF treatment caused an increase in these mRNAs (data not shown), indicating that the observed increases in specific $\mathrm{nAChR}$ transcripts were not unique to the PC12 cells used in the present study.

The expression of $\mathrm{nAChR}$ transcripts in the PKA-deficient 123.7 cells was similar to that observed in the PC12 cells (Fig. 4). In untreated 123.7 cells, RNA transcripts encoding the $\alpha_{3}$, $\alpha_{5}, \alpha_{7}, \beta_{2}$, and $\beta_{4}$ subunits were detected (Fig. 4), while those encoding the $\alpha_{2}, \alpha_{4}, \alpha_{6}$, or $\beta_{3}$ subunits were not, even upon exposure of the blot to film for 72-96 hr (data not shown).
Multiple transcripts were evident for the $\alpha_{3}, \alpha_{5}$, and $\beta_{4}$ subunits, and could be detected for the $\beta_{2}$ subunit upon longer exposures of the blot to film. Upon treatment of the cells with NGF, the same $\mathrm{nAChR}$ transcripts were expressed at 1.5-2.5 times the levels found in untreated 123.7 cells, with multiple transcripts for a given subunit appearing to be equally affected (Fig. 4). As in PC12 cells, the increases in nAChR transcript levels were consistently observed in separate experiments with different platings of cells and different lots of growth factor, and were accompanied by increases in $\mathrm{Na}$ channel $\mathrm{mRN} \Lambda$ (data not shown) that were comparable to those previously reported for these cells (Ginty et al., 1992). When combined with the results from the PC1 2 cells, the results from the PKA-deficient cells clearly show that NGF causes an increase in the steady-state levels of mRNA encoding specific nAChR subunits, and does so by means that are independent of PKA activity.

\section{Discussion}

In order to identify the molecular mechanisms that govern the expression of nAChRs and extend our understanding of the means by which NGF influences neuronal differentiation, we have used patch-clamp recording and Northern blot hybridization to analyze the effects of NGF on ACh sensitivity in PC12 cells and PKA-deficient PC12 sublines. NGF induced a significant increase in $\mathrm{nAChR}$ macroscopic current density, in accord with previous electrophysiological studies (Dichter et al., 1977; Ifune and Steinbach, 1990a). Furthermore, our results are also consistent with the two- to threefold increases in ${ }^{3} \mathrm{H}$-nicotine binding (Madhok and Sharp, 1992) and agonist-induced ${ }^{22} \mathrm{Na}^{+}$ flux (Amy and Bennett, 1983) that occur in PC12 cells in response to NGF. These results contrast with those of Rogers et al. (1992), who recently reported that the average $\mathrm{nAChR}$ current density in PC12 cells did not change upon treatment with $\mathrm{NGF}$, despite an increase in the proportion of responsive cells and a similar range of $\mathrm{nAChR}$ current densities in both untreated and treated cells. In our study, the proportion of cells responding to ACh did not increase dramatically upon treatment with NGF because most of the untreated cells had small, yet discernible responses at the outset. However, the density of $\mathrm{nAChR}$ current in individual NGF-lreated cells was often much larger than ever observed in the untreated cells, and there was a significant increase in the average current density, consistent with previous reports of NGF effects on $\mathrm{nAChR}$ expression in primary sensory neurons (Mandelzys et al., 1990) and PC12 cells (Ifune and Steinbach, 1990a). The reason for this incongruity is not clear, although it may be due to a difference in the particular subclone of PC 12 cells used by Rogers and colleagues as those authors suggest (Rogers et al., 1992).

Our analysis also included the first direct comparison of the ACh-induced single-channel activity in untreated versus NGFtreated PC12 cells. The increase in the percentage of patches with ACh-induced activity in NGF-treated cells was not accom-

\footnotetext{
Figure 3. ACh-induced single-channel currents in PC12 and 123.7 cells. For all current records, downward deflections represent channel openings, $V_{m}=-120 \mathrm{mV}$, and the current records were filtered at $4 \mathrm{kHz}$. A, Pressure application of $10 \mu \mathrm{M}$ ACh from a puffer electrode for 10 sec (beginning at arrow) elicits single-channel activity in an excised, outside-out patch of membrane from an NGF-treated PC12 cell. $B$, Representative singlechannel currents elicited by $10 \mu \mathrm{M}$ ACh in excised, outside-out patches of membrane from untreated and NGF-treated PC12 cells (left) and untreated and NGF-treated PKA-deficient 123.7 cells (right). The asterisk indicates a single-channel event of smaller amplitude than normally observed at this membrane potential. $C$, Representative current versus voltage relationships for ACh-induced single-channel events in membrane patches from untreated $(O)$ and NGF-treated $(\square)$ PC12 cells (left), and untreated $(O)$ and NGF-treated $(\square) 123.7$ cells (right). The symbols represent the mean single-channel current amplitude at the corresponding membrane potential. The solid lines drawn through the symbols were calculated by linear regression, and were used to provide an estimate of slope conductance.
} 


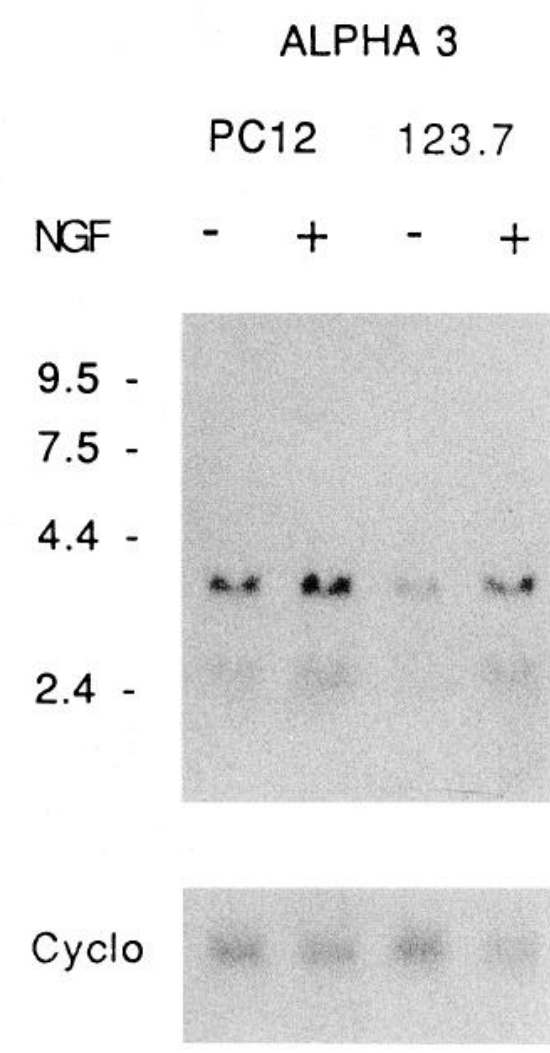

BETA 2

$\begin{array}{ll}\text { PC12 } & 123.7\end{array}$

NGF - +-+

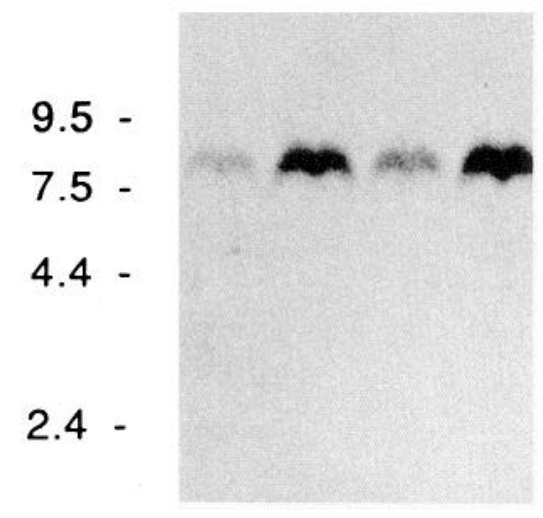

Cyclo
ALPHA 5

PC12 123.7

$\begin{array}{ll}\text { PC12 } & 123.7\end{array}$
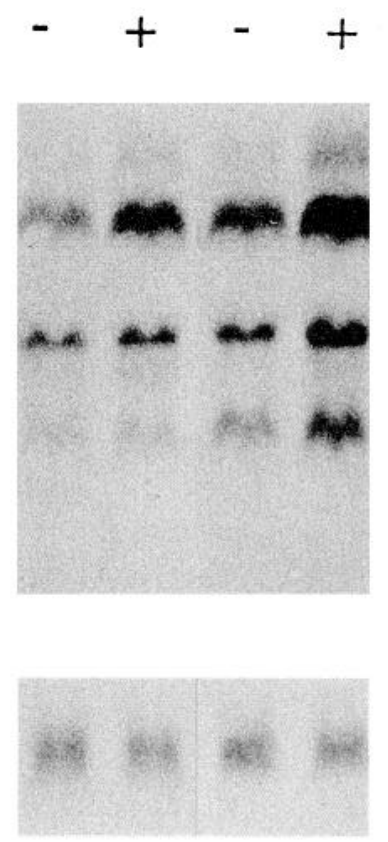

BETA 4

PC12 123.7

$-\quad+\quad+$

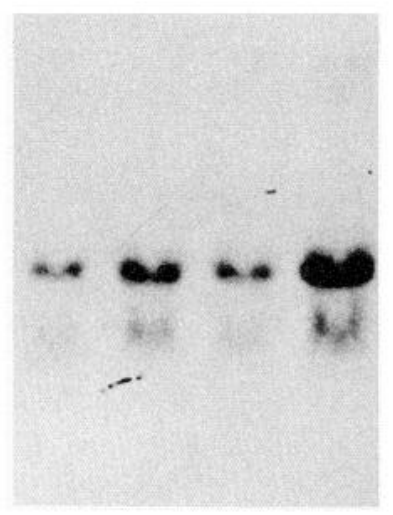

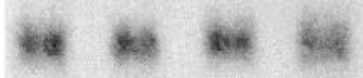


panied by obvious changes in single-channel conductance, mean burst duration, or fraction of time open. This suggests that the increased response of $\mathrm{PC} 12$ cells to ACh upon NGF treatment involves an increase in the number of functional $\mathrm{nAChRs}$ and not a dramatic change in channel type. An increase in the number of nAChRs is consistent with previous reports demonstrating NGF-mediated increases in the binding of $\mathrm{ACh}$ receptor antibodies (Whiting et al., 1987) and ${ }^{3} \mathrm{H}$-nicotine (Madhok and Sharp, 1992) to PC12 cells. Under all conditions, the predominant channel type observed in PC 12 cells had a slope conductance and a mean burst duration comparable to nAChRs previously described in PC1 2 cells (Bormann and Matthaei, 1983; Ifune and Steinbach, 1990b, 1991), bovine chromaffin cells (Fenwick et al., 1982), chick ciliary neurons (Margiotta et al., 1987), and sympathetic neurons (Listerud et al., 1991).

Results from whole-cell and single-channel recordings also provide the first evidence that a deficiency in PKA activity does not alter the constitutive expression, the NGF-stimulated expression, or the functional properties of nAChRs in PC12 cells. The NGF-stimulated increase in $\mathrm{nAChR}$ expression is similar to other PKA-independent responses to NGF, including changes in cell size, neurite outgrowth, ODC activity, and protein phosphorylation (Ginty et al., 1991, 1992). However, it is in stark contrast to the PKA-dependent changes in functional $\mathrm{Na}$ channel expression (Kalman et al., 1990; Ginty et al., 1992) and tyrosine hydroxylase phosphorylation (Cremins et al., 1986) that occur in response to NGF. In chick ciliary ganglion neurons, $\mathrm{PK} \Lambda$ appears to play a role in modulating $\mathrm{ACh}$ sensitivity, since cAMP and CAMP analogs cause a rapid increase in the number of functional channels (Margiotta et al., 1987). A rapid increase in ACh sensitivity does not appear to occur in PC12 cells, since treatment of PC12 cells with the cAMP analog 8-CPT-cAMP for 4-6 hr did not cause detectable changes in the amplitude or kinetics of the ACh-induced whole-cell currents (Henderson and Maue, unpublished observations), nor did cAMP analogs cause a detectable increase in the carbamylcholine-induced ${ }^{22} \mathrm{Na}^{+}$influx (Amy and Bennett, 1983). Furthermore, cAMP analogs do not increase the response of chromaffin cells to ACh (Dubin et al., 1992). The reason for the difference in the ability of cAMP to influence $\mathrm{nAChR}$ function in chick ciliary neurons versus PC1 2 and chromaffin cells is not clear. While there is evidence for cAMP-dependent phosphorylation of the $\alpha_{3}$ subunit expressed in chick ciliary neurons (Vijayaraghavan et al., 1990), the only mammalian subunits with consensus sites for phosphorylation by PKA are $\alpha_{4}$ (for review, see Swope et al., 1992), which does not appear to be expressed in PC12 cells (Rogers et al., 1992; present study), and $\alpha_{7}$ (Seguela et al., 1993), which may not contribute to the ACh-induced currents in these cells (Patrick and Stallcup, 1977; for discussion, see Seguela et al., 1993).

To define further the molccular mechanisms underlying
nAChR expression in PC12 cells, Northern blot analysis was used to determine the steady state levels of $\mathrm{nAChR}$ subunitspecific mRNAs in both untreated and NGF-treated PC12 and PKA-deficient 123.7 cells. The spectrum of $\mathrm{nAChR}$ subunit mRNAs expressed in $\mathrm{PC} 12$ and 123.7 cells is similar to that reported for sympathetic and parasympathetic neurons (Listerud et al., 1991; Corriveau and Berg, 1993). In PC12 and 123.7 cells, multiple transcripts were evident for the $\alpha_{3}, \alpha_{5}, \beta_{2}$, and $\beta_{4}$ subunits, as reported in previous studies (Boulter et al., 1990; Rogers et al., 1992). Although the relevance of these multiple transcripts is not clear, they are also detected in RNA from rat adrenal glands and, based on the results of RNase protection experiments, probably represent stable splicing intermediates derived from a single gene (for discussion, see Boulter et al., 1990). The results obtained from the untreated PC12 and 123.7 cells are not only in general agreement with earlier studies (Deneris et al., 1988a; Boulter et al., 1990; Rogers et al., 1992), but extend the analysis of $\mathrm{nAChR}$ expression in PC12 cells to include the $\alpha_{6}$ and $\alpha_{7}$ subunits, and provide the first documentation of $\alpha_{7}$ expression in these cells. Furthermore, the results from the untreated 123.7 cells demonstrate for the first time that the basal level of $n A C h R$ gene expression in PC12 cells occurs by mechanisms that are independent of PKA activity.

NGF treatment consistently induced increases in nAChR mRNA in PC12 and 123.7 cells. The response to NGF did not include changes in the subset of $\mathrm{nAChR}$ subunit genes that were expressed, and instead involved increases in the steady state levels of the nAChR subunit mRNAs expressed under basal conditions, with the multiple transcripts encoding a particular subunit appearing to be equally affected. In contrast, Rogers et al. (1992) reported that, with the exception of the $\beta_{2}$ mRNA, NGF treatment decreased $n A C h R$ mRNA levels. The reason for this discrepancy is not clear, and again may reside in the particular subclone of PC12 cells used in those studies, given that we observed NGF-dependent increases in nAChR transcript levels in PC1 2 cells obtained from several different sources. The increase in $\mathrm{nAChR}$ mRNA levels observed in the present study is consistent with other published results. For example, the increase in carbamylcholine-stimulated ${ }^{22} \mathrm{Na}^{+}$influx in PC12 cells upon treatment with NGF is apparently inhibited by the RNA synthesis inhibitor actinomycin D (Amy and Bennett, 1983). In addition, the approximately twofold increase in $\mathrm{nACh}$ mRNA levels observed in the present study is comparable in magnitude to other NGF-induced increases in mRNA in PC12 cells, including those for tyrosine hydroxylase and tubulin (Fernyhough and Ishii, 1987; Leonard et al., 1987; for review, see Haleguoa et al., 1991). Furthermore, the changes in $\mathrm{nAChR}$ mRNA levels are also comparable to the electrophysiological changes detected in parallel cultures of these cells. Most important, the results presented here also show for the first time that the increase in $n A C h R$ subunit mRNAs in response to NGF

\footnotetext{
Figure 4. Northern blot analysis of nAChR mRNA expression in PC12 and PKA-deficient 123.7 cells. In each blot, $40 \mu \mathrm{g}$ samples of RNA from untreated cells $(-)$ or cells treated with $100 \mathrm{ng} / \mathrm{ml} \mathrm{NGF}$ for $7 \mathrm{~d}(+)$ were analyzed using random-primed, ${ }^{32} \mathrm{P}-$ labeled probes. The position and molecular sizes of a commercially available RNA ladder (Bethesda Research Laboratories, Grand Island, NY) are shown on the left. For $\alpha_{3}$, signals at $\sim 3.9 \mathrm{~kb}$ and $2.6 \mathrm{~kb}$ are shown after $24 \mathrm{hr}$ exposure to film; for $\alpha_{5}$, signals at $\sim 10 \mathrm{~kb}, 7.8 \mathrm{~kb}, 4.5 \mathrm{~kb}$, and $2.8 \mathrm{~kb}$ are shown after $48 \mathrm{hr}$ exposure to film; for $\alpha_{7}$, a signal at $\sim 5.5 \mathrm{~kb}$ is shown after $72 \mathrm{hr}$ exposure to film; for $\beta_{2}$, a signal at $\sim 7.6 \mathrm{~kb}$ is shown after $7 \mathrm{hr}$ exposure to film; for $\beta_{4}$, signals at $\sim 5.1 \mathrm{~kb}$ and $3.5 \mathrm{~kb}$ are shown after $72 \mathrm{hr}$ exposure to film. The corresponding cyclophilin mRNA signals (Cyclo), used as an internal control to ensure that equivalent amounts of RNA were loaded in each lane and as a means of normalizing the nAChR signals during densitometric analysis, are shown after the blots were probed again with a ${ }^{32} \mathrm{P}$-labeled antisense probe specific for the $-1 \mathrm{~kb}$ cyclophilin mRNA and exposed to film for 15-30 min. Although for each case the results from one experiment are shown, consistent results were obtained in three or four separate experiments, using different platings of cells and different lots of growth factor.
} 
can occur via PKA-independent mechanisms, similar to the PKA-independent increases in c-fos, egr-1, GAP-43, transin, and type II Na channel mRNAs that occur in response to NGF (Ginty et al., 1991, 1992; Machida et al., 1991).

In the present study, NGF treatment led to an increase in the steady state levels of all of the expressed nAChR mRNAs. Although the mechanistic implications of the concomitant increase in $\mathrm{nAChR}$ subunit mRNAs are unknown, the arrangement of the $\alpha_{3}, \alpha_{5}$, and $\beta_{4}$ genes in a tightly linked gene cluster (Boulter et al., 1990) may be relevant. Additional analysis of NGF-mediated changes in $\mathrm{nAChR}$ gene expression and the regulation of individual subunit genes will be necessary to define further the mechanisms that contribute to the increases in mRNA. For example, while withdrawal from the cell cycle can, by itself, lead to accumulation of specific mRNAs (Medford et al., 1983), the increases in $\mathrm{nAChR}$ mRNA could also arise from changes in mRNA stability (Lindenbaum et al., 1988), in transcriptional activity (Gizang-Ginsberg and Ziff, 1990), or both, since NGF has been shown to influcnce gene expression in $\mathrm{PC} 12$ cells by these mechanisms (for review, see Haleguoa et al., 1991). To address these issues, as well as others, combined electrophysiological and molecular biological analyses of PC12 cells with selective alterations in signaling components should continue to provide new insights into the mechanisms underlying $n \mathrm{ACh}$ regulation and the actions of NGF, and by doing so provide an avenue toward understanding the mechanisms guiding the development and differentiation of the nervous system.

\section{References}

Amy CM, Bennett EL (1983) Increased sodium ion conductance through nicotinic acetylcholine receptor channels in $\mathrm{PC} 12$ cells exposed to nerve growth factors. J Neurosci 3:1547-1553.

Barde YA (1989) Trophic factors,and neuronal survival. Neuron 2:1525-1534

Barker PA, Murphy RA (1992) The nerve growth factor receptor: a multicomponent system that mediates the actions of the neurotrophin family of proteins. Mol Cell Biochem 110:1-15.

Bartel DP, Sheng M, Lau LF, Greenberg ME (1989) Growth factors and membrane depolarization activate distinct programs of early response gene expression: dissociation of fos and jun induction. Genes Dev 3:304-313.

Bormann J, Matthaei H (1983) Three types of acetylcholine-induced single channel currents in clonal rat pheochromocytoma cells. Neurosci Lett 40:193-197.

Bothwell M (1991) Tissue localization of nerve growth factor and nerve growth factor receptor. In: Current topics in microbiology and immunology, Vol 165 (Bothwell M, ed), pp 55-70. Berlin: Springer.

Boulter J, Evans K, Goldman D, Martin G, Treco D, Heinemann S, Patrick J (1986) Isolation of a cDNA clone coding for a possible neuronal nicotinic acetylcholine receptor alpha-subunit. Nature 319: $368-374$.

Boulter J, Connolly J, Deneris E, Goldman D, Heinemann S, Patrick J (1987) Functional expression of two neuronal nicotinic acetylcholine receptors from cDNA clones identifies a gene family. Proc Natl Acad Sci USA 84:7763-7767.

Boulter J, O'Shea-Greenfield A, Duvosin RM, Connolly JG, Wada E, Jensen A, Gardner PD, Ballivet M, Deneris ES, McKinnon D, Heinemann S, Patrick J (1990) $\alpha_{3}, \alpha_{3}$, and $\beta_{4}$ : three members of the rat neuronal nicotinic acetylcholine receptor-related gene family form a gene cluster. J Biol Chem 265:4472-4482.

Brennan C, Scotland PB, Frochncr SC, Henderson LP (1992) Functional properties of acetylcholine receptors coexpressed with the $43 \mathrm{~K}$ protein in heterologous cell systems. Dev Biol 149:100-111.

Chao MV (1992) Neurotrophin receptors: a window into neuronal differentiation. Neuron 9:583-593.

Chirgwin JM, Przybyla AE, MacDonald RJ, Rutter WJ (1979) Isolation of biologically active ribonucleic acids from sources enriched in ribonuclease. Biochemistry 18:5294-5299.
Cooper E, Lau M (1986) Factors affecting the expression of acetylcholine receptors on rat sensory neurons in culture. J Physiol (Lond) 377:409-420.

Cooper E, Couturier S, Ballivet M (1991) Pentameric structure and subunit stoichiometry of a neuronal nicotinic acetylcholine receptor. Nature 350:235-238.

Corriveau RA, Berg DK (1993) Coexpression of multiple acetylcholine receptor genes in neurons: quantification of transcripts during development. J Neurosci 13:2662-2671.

Cremins J, Wagner JA, Haleguoa S (1986) Nerve growth factor action is mediated by cAMP- and $\mathrm{Ca}^{2+}$ /phospholipid-dependent protein kinases. J Cell Biol 103:887-893.

Damon D, D'Amore PA, Wagner JA (1990) Nerve growth factor and fibroblast growth factor regulate neurite outgrowth and gene expression in PC1 2 cells via both protein kinase C-and CAMP-independent mechanisms. J Cell Biol 110:1333-1339.

Deneris ES, Connolly J, Boulter J, Wada E, Wada K, Swanson L, Patrick J, Heinemann S (1988a) Primary structure and expression of $\beta_{2}:$ a novel subunit of neuronal nicotinic acetylcholine receptors. Neuron 1:45-54.

Deneris ES, Connolly J, Boulter J, Wada E, Wada K, Swanson L, Patrick J, Heinemann $S$ (1988b) $\beta_{3}$ : a new member of nicotinic acetylcholine receptor gene family is expressed in brain. J Biol Chem 265:44724482.

Deneris ES, Connolly J, Rogers SW, Duvosin R (1991) Pharmacological and functional diversity of ncuronal nicotinic acctylcholine receptors. Trends Pharmacol 12:34-40.

Dichter MA, Tischler AS, Greene LA (1977) Nerve growth factorinduced increase in electrical excitability and acetylcholine sensitivity of a rat pheochromocytoma cell line. Nature 268:501-504.

Dubin AE, Rathouz MM, Mapp KS, Berg DK (1992) Cyclic AMP and the nicotinic response of bovine adrenal chromaffin cells. Brain Res 586:344-347.

Duvosin R, Deneris ES, Patrick J, Heinemann S (1989) The functional diversity of neuronal nicotinic acetylcholine receptors is increased by a novel subunit: $\beta_{4}$. Neuron 3:487-496.

Erny RE, Berezo MW, Perlman RL (1981) Activation of tyrosine 3-monooxygenase in pheochromocytoma cells by adenosine. J Biol Chem 256:1335-1339.

Fenwick EM, Marty A, Ncher E (1982) A patch clamp study of bovine chromaffin cells and of their sensitivity to acetylcholine. J. Physiol (Lond) 331:577-597.

Fernyhough P, Ishii DN (1987) Nerve growth factor modulates tubulin transcript levels in pheochromocytoma PC12 cells. Neurochem Res 12:891-899.

Gage FH, Tuszynski MH, Chen KS, Fagan AM, Higgins GA (1991) Nerve growth factor function in the central nervous system. In: Current topics in microbiology and immunology, Vol 165 (Bothwell M, ed), pp 71-93. Berlin: Springer.

Ginty DD, Glowacka D, DeFranco C, Wagner JA (1991) Nerve growth factor-induced neuronal differentiation after dominant repression of both type I and type II cAMP-dependent protein kinase activities. J Biol Chem 266:15325-15333.

Ginty DD, Fanger GR, Wagner JA, Maue RA (1992) The activity of cAMP-dependent protein kinase is required at a posttranslational level for the induction of voltage-dependent sodium channels by peptide growth factors in PC12 cells. J Cell Biol 116:1465-1473.

Gizang-Ginsberg E, Ziff EB (1990) Nerve growth factor regulates tyrosine hydroxylase gene transcription through a nucleoprotein complex that contains c-Fos. Genes Dev 4:477-491.

Goldman D, Deneris ES, Luyton W, Kochhar A, Patrick J, Heinemann $S$ (1987) Members of a nicotinic acetylcholine receptor gene family are expressed in different regions of the mammalian central nervous system. Cell 48:965-973.

Greene LA, Tischler AS (1976) Establishment of a noradrenergic clonal line of rat adrenal pheochromocytoma cells which respond to nerve growth factor. Proc Natl Acad Sci USA 73:2424-2428.

Grecnc LA, Tischler AS (1982) PC12 pheochromocytoma cells in neurobiology research. Adv Cell Neurobiol 3:373-414.

Haleguoa S, Patrick J (1980) Nerve growth factor mediates phosphorylation of specific proteins. Cell 22:571-581.

Haleguoa S, Armstrong RC, Kremer NE (1991) Dissecting the mode of action of a neuronal growth factor. In: Current topics in microbiology and immunology, Vol 165 (Bothwell M, ed), pp 95-118. Berlin: Springer. 
Hamill OP, Marty A, Neher E, Sakmann B, Sigworth FJ (1981) Improved patch-clamp techniques for high-resolution current recording from cells and cell-free membrane patches. Pfluegers Arch 391:85100 .

Hempstead BL, Kaplan D, Martin-Zanca D, Parada LF, Chao M (1991) High affinity NGF binding requires co-expression of the trk protooncogene product and the low affinity NGF receptor. Nature 350 $678-683$.

Ifunc CK, Stcinbach JH (1990a) Regulation of sodium currents and acetylcholine responses in PC12 cells. Brain Res 506:243-248.

Ifune CK, Steinbach JH (1990b) Rectification of acetylcholine-elicited currents in PC12 pheochromocytoma cells. Proc Natl Acad Sci USA $87: 4794-4798$

Ifune CK, Steinbach JH (1991) Voltage-dependent block by magnesium of neuronal nicotinic acetylcholine receptor channels in rat pheochromocytoma cells. J Physiol (Lond) 443:683-701.

Johnson D, Lanaham A, Buck CR, Seghal A, Morgan C, Mercer E Bothwell M, Chao M (1986) Expression and structure of the human NGF receptor. Cell 47:545-554.

Kalman D, Wong B, Horvai AE, Cline MJ, O'Lague PH (1990) Nerve growth factor acts through cAMP-dependent protein kinase to increase the number of sodium channels in PC12 cells. Neuron 2:355366.

Kaplan DR, Hempstead B, Martin-Zanca D, Chao M, Parada LF (1991a) The $t r k$ proto-oncogene product: a signal transducing receptor for nerve growth factor. Science 252:554-558.

Kaplan DR, Martin-Zanca D, Parada LF (1991b) Tyrosine phosphorylation and tyrosine kinase activity of the trk proto-oncogene product induced by NGF. Nature 350:158-160.

Klein R, Jing S, Nanduri V, O'Rourke E, Barbacid M (1991) The trk proto-oncogene encodes a receptor for nerve growth factor. Cell 65 : 189-197.

Leonard DG, Ziff EB, Greene LA (1987) Identification and characterization of $\mathrm{mRNAs}$ regulated by nerve growth factor in PC12 cells. Mol Cell Biol 7:3156-3167.

Levi-Montalcini R (1987) The nerve growth factor: thirty-five years later. EMBO J 6:1145-1 154 .

Lindenbaum MH, Carbonetto S, Grosveld F, Flavell D, Mushynski WE (1988) Transcriptional and post-transcriptional effects of nerve growth factor on expression of the neurofilament subunits in PC-12 cells. J Biol Chem 263:5662-5667.

Lindstrom J, Schoepfer R, Whiting P (1987) Molecular studies of the neuronal nicotinic acetylcholine receptor family. Mol Neurobiol 1:281337.

Listerud M, Brussaard AB, Devay P, Colman DR, Role LW (1991) Functional contribution of neuronal AChR subunits revealed by antisense oligonucleotides. Science 254:1518-1521.

Luetje C, Patrick J (1991) Both $\alpha$ - and $\beta$-subunits contribute to the agonist sensitivity of neuronal nicotinic acetylcholine receptors. $J$ Neurosci 11:837-845.

Luetje C, Wada K, Rogers S, Abramson SN, Tsuji K, Heinemann S, Patrick J (1990) Neurotoxins distinguish between different neuronal nicotinic acetylcholine receptors. J Neurochem 55:632-640.

Machida CM, Rodland KD, Matrisian L, Magun BE, Ciment G (1989) NGF induction of the gene encoding the protease transin accompanies neuronal differentiation. Neuron 2:1587-1596.

Machida CM, Scott JD, Ciment G (1991) NGF-induction of the metalloproteinase transin/stromelysin in PC12 cells: involvement of multiple protein kinases. J Cell Biol 1 14:1037-1048.

Madhok TC, Sharp BM (1992) Nerve growth factor enhances $\left[{ }^{3} \mathrm{H}\right]$ nicotine binding to a nicotinic cholinergic receptor on $\mathrm{PC} 12$ cells. Fndocrinology 130:825-830.

Mandelzys A, Cooper E (1992) Effects of ganglionic satellite cells and NGF on the expression of nicotinic acetylcholine currents by rat sensory neurons. J Neurophysiol 67:1213-1221.
Mandelzys A, Cooper E, Verge VMK, Richardson PM (1990) Nerve growth factor induces functional nicotinic receptors on rat sensory neurons in culture. Neuroscience 37:523-530.

Margiotta JF, Gurantz D (1989) Changes in the number, function, and regulation of nicotinic acetylcholine receptors during neuronal development. Dev Biol 135:326-339.

Margiotta JF, Berg DK, Dionne VE (1987) The properties and regulation of functional acetylcholine receptors on chick ciliary ganglion neurons. J Neurosci 7:3612-3622.

Meakin SO, Shooter EM (1992) The nerve growth factor family of receptors. Trends Neurosci 15:323-331.

Medford RM, Nguyen HT, Nadal-Ginard B (1983) Transcriptional and cell-cycle-mediated regulation of myosin heavy chain gene expression during muscle cell differentiation. J Biol Chem 258:1106311073.

Morgan JI, Curren T (1989) Stimulus-transcription coupling in neurons: role of cellular immediate-early genes. Trends Neurosci 12:459_ 462.

Papke RL, Heinemann S (1991) The role of the $\beta_{4}$ subunit in determining the kinetic properties of rat neuronal nicotinic acetylcholine $\alpha_{3}$ receptors. J. Physiol (Lond) 440:95-112.

Papke R, Boulter J, Patrick J, Heinemann S (1989) Single-channel currents of rat neuronal nicotinic acetylcholine receptors expressed in Xenopus oocytes. Neuron 3:589-596.

Patrick JW, Stallcup B (1977) $\alpha$-Bungarotoxin binding and cholinergic receptor function on a rat sympathetic nerve line. J Biol Chem 252: 8629-8633.

Pollock JD, Krempin M, Rudy B (1990) Differential effects of NGF FGF, EGF, cAMP, and dexamethasone on neurite outgrowth and sodium channel expression in PC12 cells. J Neurosci 10:2626-2637.

Radeke MJ, Misko TP, Hsu C, Herzenberg LA, Shooter EM (1987) Gene transfer and molecular cloning of the rat nerve growth factor receptor. Nature 325:593-597.

Rogers SW, Mandelzys A, Deneris ES, Cooper E, Heinemann S (1992) The expression of nicotinic acetylcholine receptors by $\mathrm{PC} 12$ cells treated with NGF. J Neurosci 12:4611-4623.

Seguela P, Wadiche J, Dineley-Miller K, Dani JA, Patrick JW (1993) Molecular cloning, functional properties, and distribution of rat brain $\alpha_{7}$ : a nicotinic cation channel highly permeable to calcium. J Neurosci 13:596-604.

Swope SL, Moss SJ, Blackstone CD, Huganir RL (1992) Phosphorylation of ligand-gated ion channels: a possible mode of synaptic plasticity. FASEB J 6:2514-2523.

Vernino S, Amador M, Luetje CW, Patrick J, Dani JA (1992) Calcium modulation and high calcium permeability of neuronal nicotinic acetylcholine receptors. Neuron 8:127-134.

Vijayaraghavan S, Schmid HA, Halvorsen SW, Berg DK (1990) Cyclic AMP-dependent phosphorylation of a neuronal acetylcholine receptor $\alpha$-type subunit. J Neurosci 10:3255-3262.

Wada E, Wada K, Boulter J, Deneris E, Heinemann S, Patrick J, Swanson L (1989) Distribution of alpha2, alpha3, alpha4, and beta2 neuronal nicotinic receptor subunit $m R N A s$ in the central nervous system: a hybridization histochemical study in rat. J Comp Neurol 284:314-335.

Wada K, Ballivet M, Boulter J, Connolly J, Wada E, Deneris ES, Swanson LW, Heinemann S, Patrick J (1988) Functional expression of a new pharmacological subtype of brain nicotinic acetylcholine receptor. Science 240:330-334.

Wagner JA, Kostyk SK (1991) Regulation of neural survival and differentiation by peptide growth factors. Curr Opin Cell Biol 2:10501057.

Whiting PJ, Schoepfer R, Swanson LW, Simmons DM, Lindstrom JM (1987) Functional acetylcholine receptor in $\mathrm{PC} 12$ cells reacts with a monoclonal antibody to brain nicotinic receptors. Nature 327:515518 . 